\title{
Assessing Biogeomorphological State of the Teesta River Flood Plain: A Study on Gangachara Upazila, Rangpur, Bangladesh
}

\author{
Sahidul Islam, Subaran Chandra Sarker* \\ Department of Geography and Environmental Science, Begum Rokeya University, Rangpur, Bangladesh \\ Email: *suba.ju23@gmail.com
}

How to cite this paper: Islam, S. and Sarker, S.C. (2017) Assessing Biogeomorphological State of the Teesta River Flood Plain: A Study on Gangachara Upazila, Rangpur, Bangladesh. International Journal of Geosciences, 8, 265-275. https://doi.org/10.4236/ijg.2017.82011

Received: January 9, 2017

Accepted: February 25, 2017

Published: February 28, 2017

Copyright ( 92017 by authors and Scientific Research Publishing Inc. This work is licensed under the Creative Commons Attribution International License (CC BY 4.0).

http://creativecommons.org/licenses/by/4.0/ (c) (i) Open Access

\begin{abstract}
Teesta river flood plain is one of the most significant landscapes in Bangladesh. The main theme of this research was to assess the present biogeomorphological state (biomass, herbaceous vegetation species, density of all vegetation species, flood plain extension mapping) of Teesta river flood plain under Gangachara upazila. The research work was conducted based on the objectives to prepare a map of Teesta river flood plain extension area, to estimate herbaceous vegetation (biomass, species types), and to find out the vegetation density to assess the present biogeomorphological state of study area. To present the flood plain area of Teesta river in the Gangachara upazila, base map has been used; herbaceous vegetation samples have been collected through quadrat method to estimate biomass (both in dry and before dry condition) using digital weight machine; vegetation density has been shown through NDVI of satellite image (Landsat-8) using red and NIR band in ArcGIS 10.1 software. From the results of this research, river flood plain area is found 68.5 sq. km; total 31 types of herbaceous species have been identified where Pouzolzia indica is the most dominated species covering $11.59 \%$ of the total area; maximum DNs value of NDVI is found +0.475242 which represents the highest vegetation density covering an area of $78 \mathrm{sq}$. $\mathrm{km}$ of the total area. The research may assist for the further study of river flood plain biogeomorphology throughout the country as well as in the world.
\end{abstract}

\section{Keywords}

River Flood Plain, Biomass, NDVI, Herbaceous Vegetation, Quadrat

\section{Introduction}

River flood plains are among the most fertile and richest ecosystems on the 
earth, thus, it has been very essential to manage properly. Biogeomorphological state of any river flood plain indicates the usefulness of it. Study of herbaceous vegetation (biomass, species types) through quadrat method, NDVI, is significantly helpful to bring out the present real scenario of biogeomorphological state of a river flood plain area. River flood plains are important landscapes features for retaining river nutrients and sediment loads [1]. The river flood plain is typically defined as narrow strip on each side of the river channel [2]. Thus, flood plain lies between natural levee and flood basin and is lower in elevation than that of natural levee [3]. This is primarily due to periodical floodplain inundation [4], thus is seasonal recruitment habitat [5] which replenishes the soil nutrients and sustains a high level of landscape diversity. River flood plains are environments that alternate between wet and dry phases, with lower lying parts being wet than dry and higher parts being more dry than wet [6]. Flood plains are habitat for terrestrial biota during dry phase, and in wet phase, flood plains are habitat for aquatic fauna and mobile species such as fishes, grasses, etc. [7]. Historically, humans have used rivers flood plain more than any other types of ecosystem [8]. The term biogeomorphology was first used in the eighties [9]; biogeomorphology is a relatively new discipline within the study of river flood plain system. Biogeomorphological (flora and fauna based on the development of land formation) state of any landscape helps us to understand the fertility, productivity as well as the total ecological scenario of the specific region [10]. Herbaceous vegetation species' (density, biomass) study based on satellite imageries provides an idea of river flood plain ecology [11]. Biomass measurement of vegetation (herb, shrub and tree) using quadrat method is an important ecological property to understand the river flood plain landscape pattern [12]. Vegetation types related to basin geomorphology will provide a basis for future restoration planning regarding river flood plain [13].

The Teesta river flood plain presents a very typical biological and geomorphological characteristic and behavior. This river channel represents a normal flow of the moribund and mature hydrological situations of a flood plain environment. Although the Teesta presently carries a very poor discharge of water, still it is the major river of the northern part of Bangladesh influencing greatly in the agricultural sector and as a major tributary of Jamuna River [14]. The Teesta river flood plain plays a vital role in the overall ecological and socio-economic life of Gangachara upazila. At least 75,000 [15] thousands of people Gangachara upazila are somehow dependent on the Teesta and its biogeomorphological settings. It is a time of concerning to study about river flood plain for ensuring the current human demand due to rapid growth of population and industrialization. River flood plain of Gangachara upazila developed by Teesta river flowing from the northern part of Bangladesh toward southern part as major tributary of Jamuna river is biogeomorphologically as well as geopolitically significant to study. That is why assessment of herbaceous vegetation biomass using quadrat method and NDVI using Landsat satellite image were adopted to find out the present biogeomorphological state of Teesta river flood plain area. 


\section{Study Area}

River flood plain is one of the most significant landscapes that historically roles in livelihood of human being including socio economic as well as cultural aspects through its diverse and effective ecological settings that is why it is considered as biological super market. At present, river flood plain is more concerning issue throughout the world. In this research the study area biogeomorphologically is facing vulnerable situation day by day as it is losing adequate amount of water discharge from upper stream due to geopolitical issues between Bangladesh and India. It is time to think about the problem to manage the flood plain area. Teesta river flood plain is the most significant landscape in the northwestern part of Bangladesh that falls in the old Himalayan piedmont plain comprising of recent flood plain deposits [16]. The Teesta river flood plain in the Gangachara upazila presents a very typical biological and geomorphological characteristics or behavior. The present study area map provided from BWDB is located in the Gangachara upazila under the Rangpur district of northern part of Bangladesh. Figure 1 shows that Gangachara upazila is located between $25^{\circ} 48^{\prime}$ and $25^{\circ} 57^{\prime}$ north latitudes and between $89^{\circ} 05^{\prime}$ and $89^{\circ} 21^{\prime}$ east longitudes covering an area $272.28 \mathrm{sq}$. $\mathrm{km}$ where total land area of $206.45 \mathrm{sq}$. km, is bounded by Kaliganj (Lalmonirhat) and Jaldhaka (Nilphamari) upazilas on the north, Rangpur Sadar and Kaunia upazilas on the south, Aditmari and Lalmonirhat sadar upazilas on the east, Kishoreganj (Nilphamari) and Taraganj upazila on the west.

\section{Materials and Methods}

\subsection{Materials}

The research work has been conducted based on the both primary and secondary data sources; primary data has been collected through field survey regarding herbaceous vegetation from the study area. Secondary data were collected through

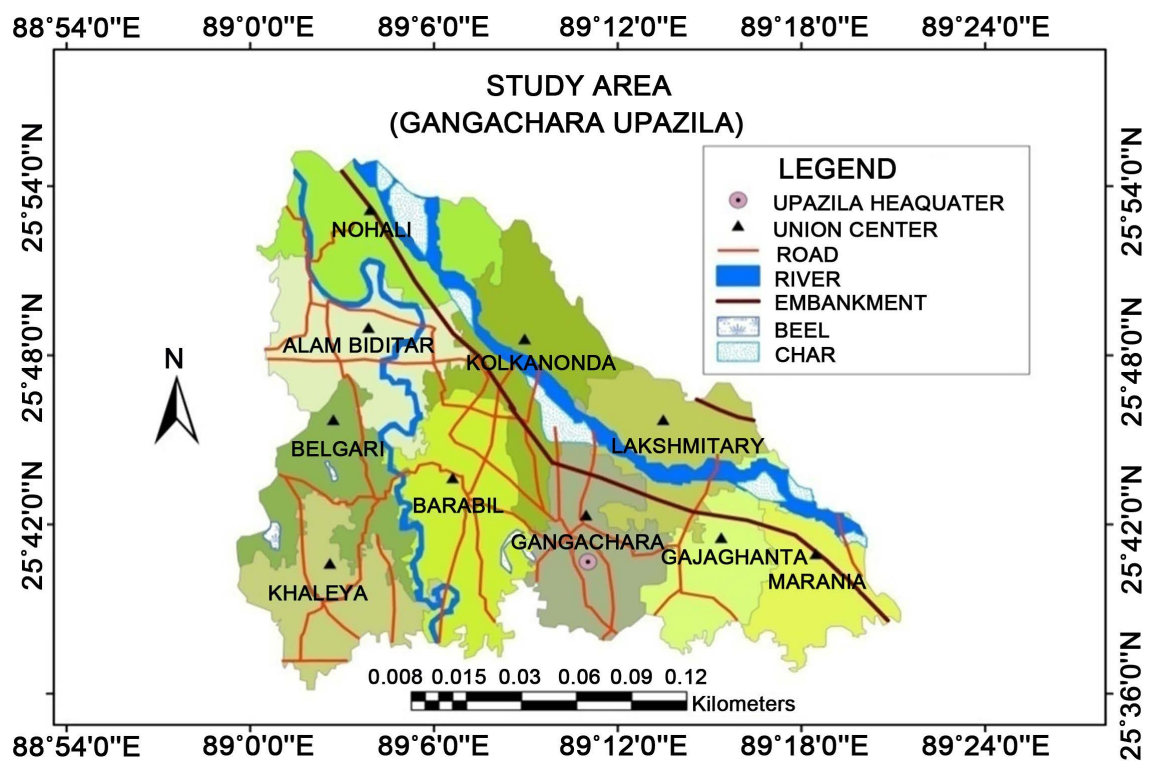

Figure 1. Map of the study area (Gangachara upazila). 
base map provided from BWDB, satellite image (Landsat-8) was collected from SPARSSO, and data has been processed using MS Excel, ArcGIS 10.1, and ArcGIS 9.3 software.

\subsection{Methods}

The research work has been conducted based on considering about the biogeomorphological state of Teesta river flood plain in Gangachara upazila, there has been selected the study about mapping of flood plain area, herbaceous vegetation (biomass, species type), vegetation density, and where map of Teesta river flood plain extension area has been made using ArcGIS 9.3 software based on the study of base map provided by BWDB. For the measuring biomass of herbaceous vegetation total 104 sampling area has been selected through quadrat method using 1 square feet bamboo frame after the distance of every 200 meter that covered total area 104 sq. feet in river flood plain area, after collecting herbaceous species from the river flood plain area biomass has been measured both in dry $\left(40^{\circ} \mathrm{C}\right.$ oven drying) and before dry condition using digital weight machine, in the study of herbaceous vegetation, there have found 31 species in the river flood plain area that have been identified after the procedure of ICBN (International Code of Botanical Nomenclature). Satellite image of vegetation condition of 2015 was acquired on March 8 (with a map projection of WGS_ 84) has been used for the NDVI mapping to know present state of vegetation scenario of the study area. The image was stacked in the ArcGIS 10.1 software for image classification to make NDVI. Those three processes mostly help in assessing about the biogeomorphological state of river flood plain area as well as Teesta river flood plain in Gangachara upazila.

\section{Result and Discussion}

\subsection{Mapping of Teesta River Flood Plain Extension Area in Gangachara Upazila}

The study area showed in Figure 2 about the delineation of Teesta river flood plain area and other types of landformation in the Gangachara upazila.

Table 1 showed that total area of Gangachara upazila is $272.28 \mathrm{sq}$. $\mathrm{km}$ from where Teesta river flood plain area was found out 68.5 sq. km covered by $25.15 \%$ of the total area based on the measuring regularly inundated area by Teesta river in which average length in both bank side was $27.4 \mathrm{~km}$ and average wide of flood plain from bank up to 500 meter $(0.5 \mathrm{~km})$ toward landmass in southern part where as average width in the northern part was found $2 \mathrm{~km}$.

Figure 3 represented total river flood plain area covering $25.15 \%$ of the total, and $74.85 \%$ was covered by the other types of land formation in the study area.

\subsection{Records of Herbaceous Vegetation of Teesta River Flood Plain in the Gangachara Upazila}

The biomass pattern of study area has been estimated in square feet for every sample. Through the quadrat method sampling was taken. The depiction in the 


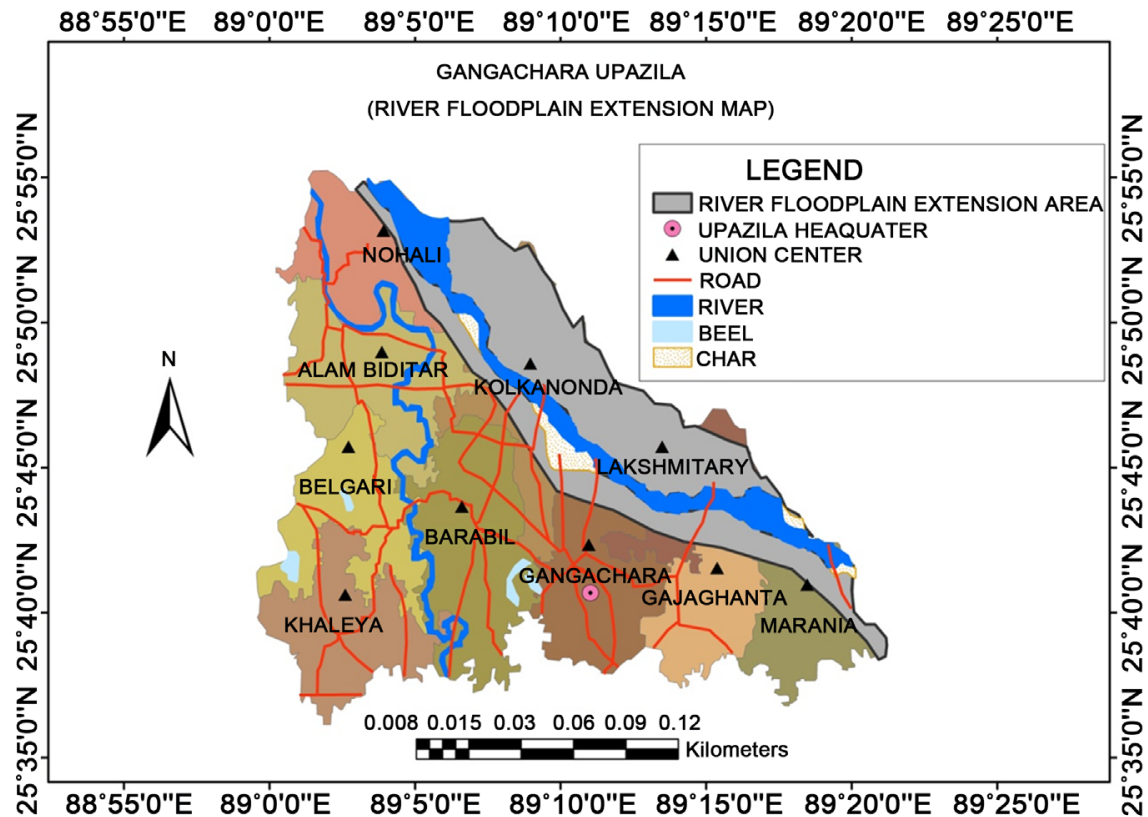

Figure 2. Teesta river flood plain extension area in the Gangachara upazila.

\section{Amount of Teesta river flood plain area and other types in Gangachara upazila}

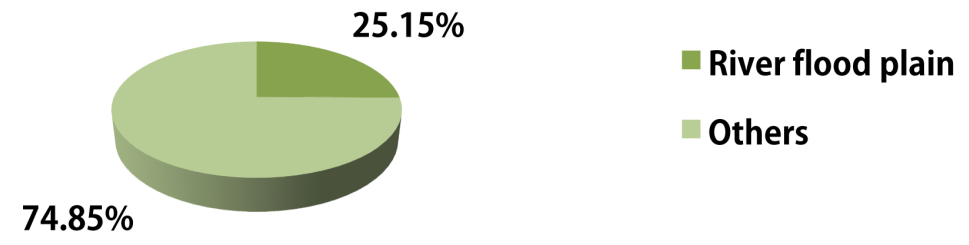

Figure 3. Amount of Teesta river flood plain area and other types in the Gangachara upazila.

Table 1. Amount of Teesta river flood plain area and other types in the Gangachara upazila.

\begin{tabular}{cccc}
\hline Total area $($ sq. $\mathrm{km})$ & Category & Area & Percentage (\%) \\
\hline \multirow{2}{*}{272.28} & River flood plain & 68.5 & $25.15 \%$ \\
& Others & 203.78 & $74.85 \%$ \\
\hline
\end{tabular}

Table 2 narrates that the total sampling area was 104 square feet. Total biomass in green condition (before dry) was $7.719 \mathrm{~kg} / 104$ sq. feet; total biomass after dry of vegetation was $3.191 \mathrm{~kg} / 104$ sq. feet, and the difference between two biomass pattern (before dry and after dry of vegetation) is $4.528 \mathrm{~kg} / 104 \mathrm{sq}$. feet. Total number of species population was 11,343, where species type total was 31 .

\subsubsection{Biomass Pattern of Herbaceous Vegetation of Teesta River Flood Plain in the Gangachara Upazila}

Table 3 showed that the total sampling areas were 104 sq. feet, where total biomass of herbaceous vegetation $7.719 \mathrm{~kg}$ (before dry) that covered $70.75 \%$ of total area and $3.191 \mathrm{~kg}$ in (after dry) that covered $29.24 \%$ of total area. 
Table 2. Records of herbaceous vegetation (biomass, number of species type) of Teesta River flood plain area in the Gangachara upazila.

\begin{tabular}{cccccc}
\hline $\begin{array}{c}\text { Total } \\
\text { surveyed } \\
\begin{array}{c}\text { area } \\
\text { (sq. feet) }\end{array}\end{array}$ & $\begin{array}{c}\text { Total } \\
\text { biomass } \\
\text { (before dry) }\end{array}$ & $\begin{array}{c}\text { Total } \\
\text { biomass } \\
\text { (after dry) }\end{array}$ & $\begin{array}{c}\text { Difference } \\
\text { between } \\
\text { biomass } \\
\text { (before and } \\
\text { after dry) }\end{array}$ & $\begin{array}{c}\text { Total number } \\
\text { of population } \\
\text { (density/sq. feet) }\end{array}$ & $\begin{array}{c}\text { Total no. } \\
\text { of identified } \\
\text { species }\end{array}$ \\
\hline 104 & $7.719 \mathrm{~kg}$ & $3.191 \mathrm{~kg}$ & $4.528 \mathrm{~kg}$ & 11343 & 31 \\
\hline
\end{tabular}

Table 3. Total amount of herbaceous vegetation biomass (before dry and after dry) in the Teesta river flood plain area (Gangachara upazila).

\begin{tabular}{cccc}
\hline Total area (sq. feet) & \multicolumn{2}{c}{ Biomass of herbaceous vegetation (Kg.) } & Percentage (\%) \\
\hline \multirow{2}{*}{104} & Biomass (before dry) & 7.719 & $70.75 \%$ \\
& Biomass (after dry) & 3.191 & $29.24 \%$ \\
\hline
\end{tabular}

According to Figure 4 biomass before dry condition of herbaceous vegetation was three times larger than biomass in after dry of vegetation; the difference was due to the result of drying vegetation in $40^{\circ} \mathrm{C}$ in oven as moisture, water content and others content in the vegetation is lost. So, net biomass is $4.528 \mathrm{~kg}$.

In Table 4, there has been shown biomass of herbaceous vegetation of the Teesta river flood plain area as average, maximum and minimum both in dry and before condition for comparative analysis through field survey. These patterns of biomass have been found through the measuring of the total 104 quadrat samples separately in the study area. Each sample has been measured separately in where maximum value of a quadrat covered sample showed $0.210 \mathrm{gm} / \mathrm{sq}$. feet in the before dry condition of herbaceous vegetation and that showed $0.088 \mathrm{gm} / \mathrm{sq}$. feet in after dry condition. Like that a sample contained the value $0.001 \mathrm{gm} / \mathrm{sq}$. feet represented minimum amount of biomass pattern which has been showed $0.00024 \mathrm{gm} / \mathrm{sq}$. feet in after dry condition and average value of biomass were showed $0.07 \mathrm{gm} / \mathrm{sq}$. feet and $0.03 \mathrm{gm} / \mathrm{sq}$. feet comparatively in before dry and after dry condition of herbaceous vegetation. Figure 5 showed the comparison of biomass pattern in the study area.

\subsubsection{Density of Identified Herbaceous Species in the Flood Plain of Gangachara Upazila}

Table 5 represented that there has been found 31 types of herbaceous vegetation species in the study area. The most dominated species type of the Teesta river flood plain area in the Gangachara upazila was Pouzolzia indica (moishma ghas) that covered at about $11.59 \%$ of total area and the lowest type of species was $\mathrm{Ca}$ locasia esculenta (kachu), Mimosa padica (lajjabati) etc. that covered $0.31 \%$ of total area.

\subsection{NDVI and Vegetation Density Map of Gangachara Upazila}

Figure 6 showed that, green color containing DN value 0.475242 represented highest vegetation covered area on the other hand red color containing DN value 
Table 4. Maximum, minimum and average amount of biomass (before dry and after dry) in the Teesta river flood plain area of Gangachara upazila.

\begin{tabular}{cccc}
\hline Biomass of vegetation & Category & Amount (gm/sq. feet) & Percentage (\%) \\
\hline \multirow{2}{*}{ Before dry } & Average & 0.07 & $24.91 \%$ \\
& Maximum & 0.210 & $74.73 \%$ \\
& Minimum & 0.001 & $0.36 \%$ \\
\multirow{2}{*}{ After dry } & Average & 0.03 & $25.37 \%$ \\
& Maximum & 0.088 & $74.42 \%$ \\
& Minimum & 0.00024 & $0.21 \%$ \\
\hline
\end{tabular}

Table 5. Density of identified herbaceous species in the Teesta river flood plain area of Gangachara upazila.

\begin{tabular}{|c|c|c|c|}
\hline SL. NO. & Local Name & Scientific Name & Density (\%) \\
\hline 01 & Moishma ghas & Pouzolzia indica & 11.59 \\
\hline 02 & Amrul & Oxalis corniculata & 9.09 \\
\hline 03 & Moina ghas & Cymbopogan citratus & 8.15 \\
\hline 04 & Chapra ghas & Elusine indica & 6.89 \\
\hline 05 & Durba ghas & Cynodon dactylon & 5.95 \\
\hline 06 & Kelna ghas & Cyperus rotundus & 5.64 \\
\hline 07 & Nunia shak & Portulaca oleracea & 5.64 \\
\hline 08 & Helencha & Aristida leucas & 4.38 \\
\hline 09 & Fotka & Physalis micrantha & 4.38 \\
\hline 10 & Bilaikhamchi & Achyranthes aspera & 4.38 \\
\hline 11 & Bicha ghas & Kyllinga nemoralis & 4.07 \\
\hline 12 & Kalmi & Ipomoea aquatica & 3.44 \\
\hline 13 & Okhra & Chrysopgon aciculatus & 3.44 \\
\hline 14 & Notay shak & Amaranthus viridis & 3.13 \\
\hline 15 & Keshuti & Eclipta alba & 2.50 \\
\hline 16 & Bhuishak & Ludwigia hyssopifolia & 2.50 \\
\hline 17 & Kanta morich & Amaranthus spinosus & 2.50 \\
\hline 18 & Muktajhuri & Acalypha indica & 1.56 \\
\hline 19 & Jhunjhuni ghas & Croton bonplandia & 1.56 \\
\hline 20 & Bish Dhekia & Pteris pellucida & 1.56 \\
\hline 21 & Bishkatali & Persicaria barbata & 1.56 \\
\hline 22 & Keshur & Actinoscirpus grossus & 1.25 \\
\hline 23 & Lal Bishkatali & Persicaria acuminata & 1.25 \\
\hline 24 & Kanshisa & Leucas aspera & 0.62 \\
\hline 25 & Foksa & Cyperus laxus & 0.62 \\
\hline 26 & Shada Dhekia & Diplazium esculentum & 0.62 \\
\hline 27 & Kachu & Calocasia esculenta & 0.31 \\
\hline 28 & Lajjabati & Mimosa padica & 0.31 \\
\hline 29 & Shoti & Curcuma zedoaria & 0.31 \\
\hline 30 & Pan pata & Peperomia pellucida & 0.31 \\
\hline 31 & Bish Kachu & Alocasia cucullata & 0.31 \\
\hline
\end{tabular}




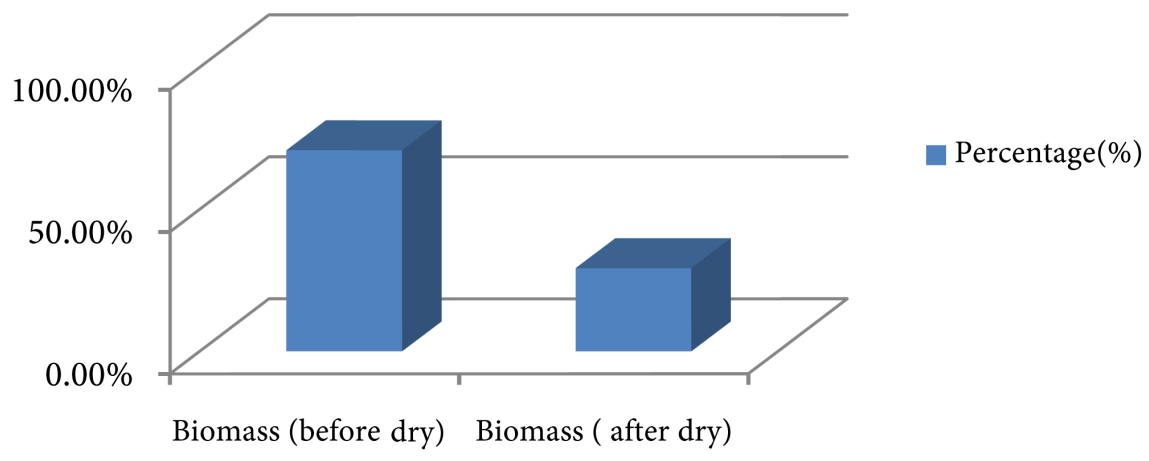

Figure 4. Biomass condition of herbaceous vegetation in the Teesta river flood plain area under Gangachara upazila.

\section{Biomass pattern before dry of vegetation}

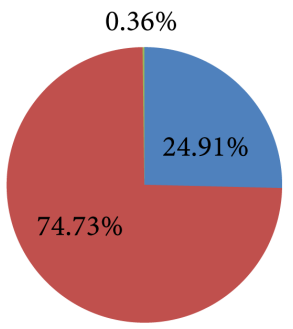

\section{Biomass pattern after dry of vegetation}

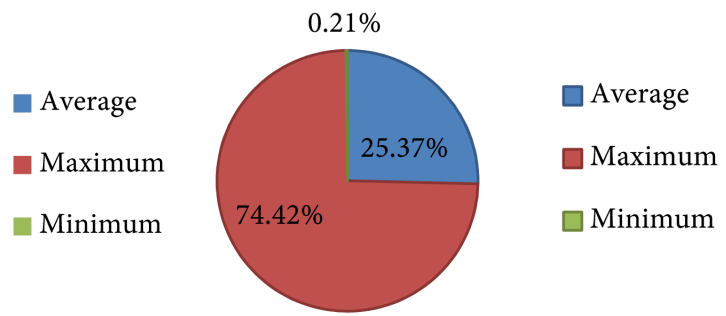

Figure 5. Comparison of biomass in different pattern both before dry and after dry of herbaceous vegetation.

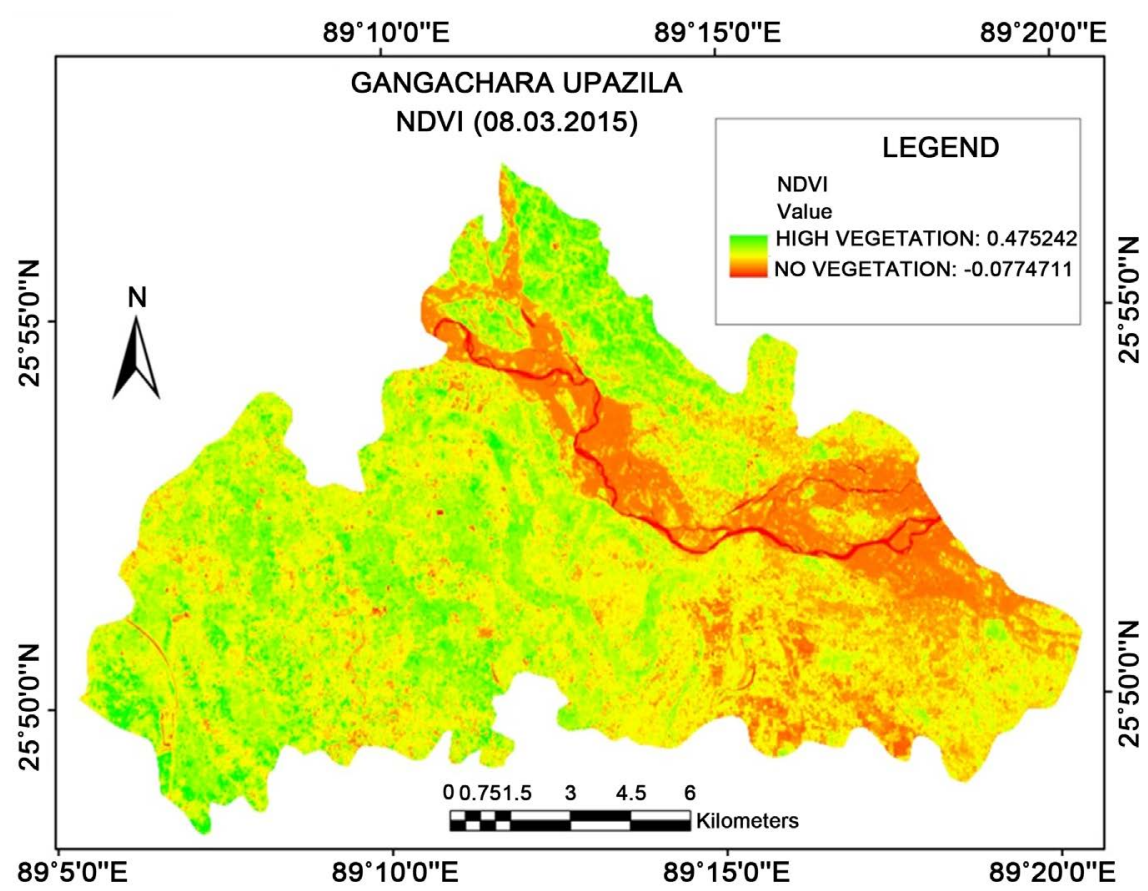

Figure 6. NDVI map of vegetation of Gangachara upazila.

-0.0774711 represented no presence of vegetation and Figure 7 has been prepared for showing density pattern of vegetation of Gangachara upazila. 


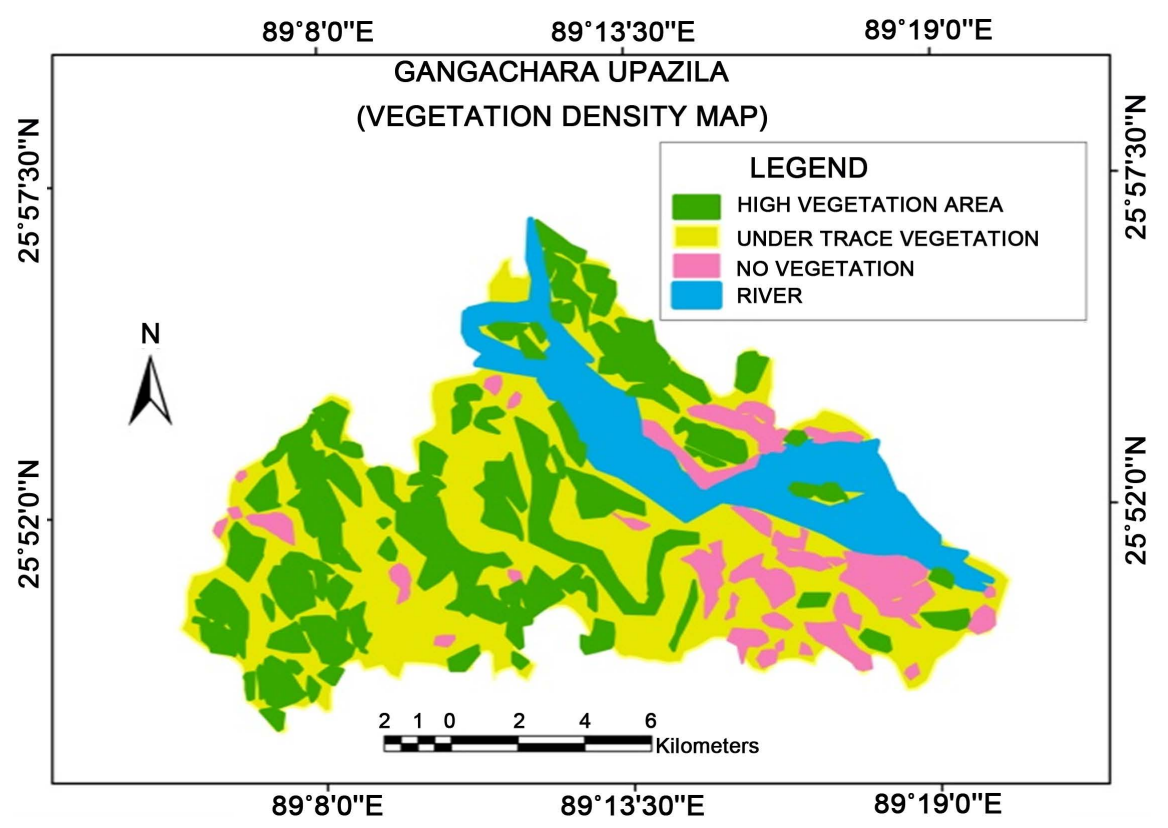

Figure 7. Density map of vegetation of Gangachara upazila.

\section{Vegetation Covered Area of the Gangachara Upazila in 2015}

Table 6 represented the different category of vegetation covered in the study area and Figure 8 represented that high vegetation covered area in Gangachara upazila is $78 \mathrm{sq}$. $\mathrm{km}$ which covers $28.64 \%$ of total area, where as under trace vegetation was covered $61.08 \%$ and no vegetation was covered $10.28 \%$ in the Gangachara upazila.

\section{Conclusion}

The aim of the study was to assess the present biogeomorphological state of the Teesta river flood plain area. The present research work was based on the combine application of field survey, lands at satellite image processing, flood plain extension mapping, etc. Firstly, total river flood plain area has been estimated 68.5 sq. km, from that flood plain area, herbaceous vegetation samples have been collected to analyze biomass state where total sampling area is 104 sq. feet and total 31 types of herbaceous species are identified. NDVI operation has been run to find out the mostly vegetation covered area classified into dense vegetation and no vegetation covered area; the DNs value of NDVI is 0.475242 representing high vegetated areas and the DNs value -0.0774711 shows no vegetation covered area in the Gangachara upazila. However, based on the analyzing of herbaceous vegetation biomass, NDVI, the present biogeomorphological state of Teesta river flood plain area under Gangachara upazila was assessed, where especially the condition of herbaceous vegetation was assessed based on showing species types and biomass in dry and before dry condition. It has been found that, Teesta river flood plain changes its real nature due to many types of human interruptions and loses its biological status. So, it is a burning issue to study its current biological state. In accordance with that, the herbaceous vegetation study and NDVI operation have been adopted. This research will provide important guidelines 


\section{Vegetation density of Gangachara upazila in $\mathbf{2 0 1 5}$}

$10.28 \%$

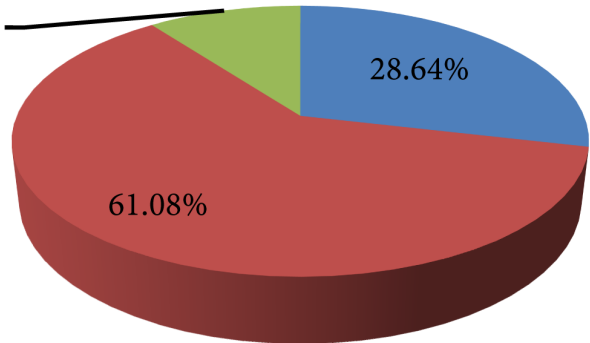

High vegetation covered

Under trace vegetation

No vegetation

Figure 8. Pattern of vegetation density of Gangachara upazila in 2015.

Table 6. Vegetation density in the Gangachara upazila, 2015.

\begin{tabular}{cccc}
\hline Total area $(\mathrm{sq} . \mathrm{km})$ & Category & Area (sq. km) & Percentage (\%) \\
\hline \multirow{2}{*}{272.28} & High vegetation covered & 78 & $28.64 \%$ \\
& Under trace vegetation & 166.28 & $61.08 \%$ \\
& No vegetation & 28 & $10.28 \%$ \\
\hline
\end{tabular}

for better use of river flood plain area as well as will assist river planners, researchers, engineers, administrator, geographer, farmers, and local inhabitants in their respective fields fruitfully.

\section{Acknowledgements}

Authors would like to acknowledge SPARSSO, BWDB and chairman of the Department of Botany of Carmichael College for providing necessary data for the purpose of completing the research work.

\section{References}

[1] Harper, R.M. (1911) The Riverbank Vegetation of the Lower Apalachicola, and a New Principal Illustrated Thereby. Torreya, 11, 225-234.

[2] Pressey, R.L. (1986) Wetlands of the River Murray. RMC Environmental Report 86/1, River Murray Commission.

[3] Dunbar, C.O. and Rodgers, J. (1957) Principles of Stratigraphy. Wiley International Edition, Toppan Company Ltd., Tokyo, 271-288.

[4] Cohen, W.B. and Goward, S.N. (2004) Landsat's Role in Ecological Applications of Remote Sensing, Bioscience, 54, 535-545.

https://doi.org/10.1641/0006-3568(2004)054[0535:LRIEAO]2.0.CO;2

[5] King, A.J., Humphries, P. and Lake, P.C. (2003) Fish Recruitment on Flood Plains: The Roles of Pattern of Flooding and Life History Characteristics. Canadian Journal Fisheries and Aquatic Science, 60, 773-786. https://doi.org/10.1139/f03-057

[6] Young, W.J. (2001) Rivers as Ecological System: The Murray Darling Basin. CSIRO Land and Water, Canberra.

[7] Leslie, D.J. (2001) River Murray Environmental Flows 2000-2001. Ecological Management and Restoration, 3, 221-223.

[8] Arthington, A.H., Stuart, E. and Anzel, B. (2002) Basic Principles and Ecological Consequences of Altered Flow Regims for Aquatic Bio Diversity. Environmental 
Management, 30, 492-507. https://doi.org/10.1007/s00267-002-2737-0

[9] Viles, H.A. (1988) Biogeomorphology. Blackwell, Oxford.

[10] Nislow, K.H. (2005) The Regulation of Peace River: A Case Study for River Management. River Research and Application, 18, 429-446.

[11] Nally, R. (2002) Habitat Change and Restoration: Responses of Forest Floor Mammal Species to Manipulations of Fallen Timber in Flood Plain Forest. Animal Biodiversity and Conservation, 25, 41-51.

[12] Campbell, J.B. (1981) Spatial Correlation Effects upon Accuracy of Supervised Classification of Land Cover. Photogrammetric Engineering \& Remote Sensing, 47, 355363.

[13] Christine, F. (2015) Biotic Controls on $\mathrm{CO}_{2}$ and $\mathrm{CH}_{4}$ Exchange in Wetlands-A Closed Environment Study. Biogeochemistry, 64, 337-354. https://doi.org/10.1023/A:1024913730848

[14] Ahmed, A.U., Neelormi, S., Adri, N., Alam, M.S. and Nurruzzaman (2014) Climate Change, August 2007. Dhaka, 86.

[15] Bangladesh Bureau of Statistics (BBS) (2011) Statistical Year Book of Bangladesh.

[16] Khan, F.H. (1991) Geology of Bangladesh. University Press Limited, Dhaka, 207.

Submit or recommend next manuscript to SCIRP and we will provide best service for you:

Accepting pre-submission inquiries through Email, Facebook, LinkedIn, Twitter, etc. A wide selection of journals (inclusive of 9 subjects, more than 200 journals)

Providing 24-hour high-quality service

User-friendly online submission system

Fair and swift peer-review system

Efficient typesetting and proofreading procedure

Display of the result of downloads and visits, as well as the number of cited articles

Maximum dissemination of your research work

Submit your manuscript at: http://papersubmission.scirp.org/

Or contact ijg@scirp.org 